\title{
DISSENT IN THE WIRTSCHAFTSWUNDER
}

\section{Historical Memory and the German Student Movement}

THIS PAPER DEALS WITH THE WEST GERMAN STUDENT MOVEMENT, WHICH, LIKE MOST STUDENT MOVEMENTS, WAS ACTIVE IN THE 1960S AND FOCUSED PRIMARILY ON SOCIAL ISSUES. IT ATTEMPTS TO INTERPRET THE CRITIQUES LEVIED BY THE MOVEMENT IN RELATION TO THOSE EVENTS AND THOUGHTS WHICH PRECEDED IT. THE AUTHOR ARGUES THAT THERE WAS A DISTINCT RHETORICAL AND PHILOSOPHICAL CONNECTION BETWEEN THE 68ER-BEWEGUNG AND THE CRITICAL THEORY OF THE FRANKFURT SCHOOL. THIS CONNECTION SHAPED THE METHODS AND GOALS OF THE STUDENT MOVEMENT, WHICH SOUGHT TO INTEGRATE A PROCESS OF COMING TO TERMS WITH THE REALITIES OF GERMANY'S FASCIST, ANTI-DEMOCRATIC PAST INTO THE GERMAN MINDSET FOLLOWING THE RICH PERIOD OF REMARKABLE POSTWAR ECONOMIC DEVELOPMENT. THESE METHODS AND INFLUENCES, WHICH ARE CALLED “CRITICAL HISTORICAL MEMORY," ARE THEN ARGUED TO HAVE BEEN DEPLOYED SO AS TO BRING TO LIGHT THE CONTINUED PRESENCE OF FASCISTIC TENDENCIES IN CONTEMPORARY GERMAN POLITICS, WITH THE HOPE OF COMING TO TERMS WITH THE RECENT PAST. 
The writings, speeches, and pamphlets of the German student movement display a contemporarily unique approach to historical memory. The period following World War II called for a historical reckoning of recent events in Germany. Due to conditions on the ground, however, such immediacy was either made impossible by turmoil or forced and subsequently repressed by denazification. Given its ostensibly democratic structure and ideals, Western Germany seemed positioned for a reckoning of memory and conscience with the dawn of a new sovereignty in the midI950s. As Konrad Adenauer and his administration regained the reigns of governance, though, the extent to which a recovery of conscious, critical historical memory occurred is unclear. While West German economic standards rose rapidly to levels similar to their Western allies, it is not evident that there was any discourse aimed at coming to terms with the fascist, antidemocratic tendencies that had until recently carried so much political and cultural clout. Indeed, in the nexus that became known as the German student movement, or the 68er-Bewegung, the criticism that the recovery to date had been merely material and disturbingly ahistorical is brought to light. In this sense, the German student movement can be interpreted as movement of critical historical memory.

An outline of this concern is found in a speech titled "The Students and the Revolution," delivered by Rudi Dutschke, a figurehead of the movement. Dutschke stated that, "In the fifties the Left in West Germany believed that capitalism no longer contained any contradictions." The old guard, Dutschke claimed, had acquiesced too readily to an easy definition of progress, a superficial economic solution that attempted to pave over the problematic parts of recent history. To understand both Dutschke's speech and the movement it epitomized, one must observe the insistence on historical memory that spurred the movement's inception, how this concern impacted the movement's means of demonstration, and to what degree it was successful in its complicated conclusion.

The fact that critique of recent history occurred in German universities is, in one sense, historically expected. In Western Germany, between I960 and I966, there was a precipitous rise in the student population from I95,000 to 281,000, resulting in overcrowded facilities and reduced contact with faculty. ${ }^{2}$ While this would be cause for alarm in any political climate, it resulted in particularly shocking outcomes in Western Germany due to a number of factors external to the university. The student body felt stifled and politically impotent. As Willibald Karl notes in The Journal

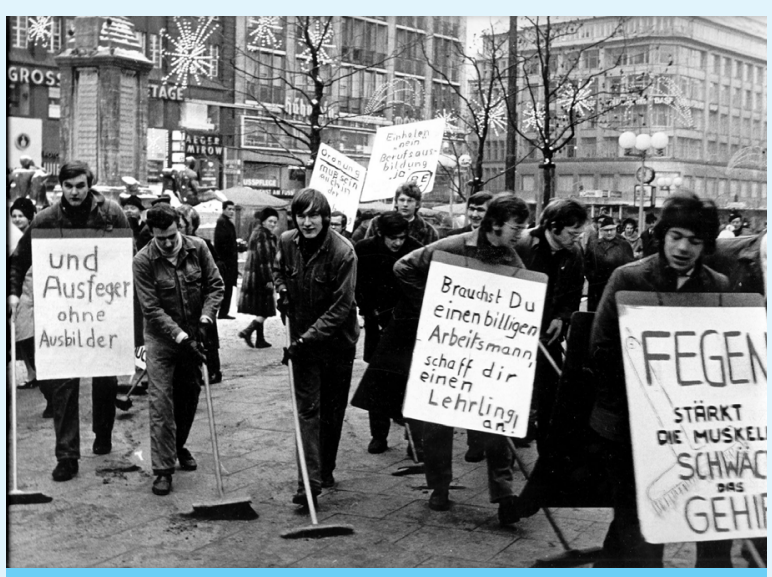

1968 HAMBURG LEHRLING DEMONSTRATION (COURTESY OF WIKIMEDIA COMMONS)

of Contemporary History, the student unions of various German universities "proved [themselves] incapable of meeting the needs of the students or of getting their demands accepted." ${ }^{3}$ As a result, the students sought political means of recourse - specifically in the socially liberal, and classically socialist, Sozialdemokratische Partei Deutschlands (SPD.) However, the SPD, in its I959 party convention, had abandoned its classical Marxist views in favor of a capitalistic, social market economy platform, beginning a process of what Michael Schmidtke of the University of Bielefeld termed "de-ideologization."4 Those ideals, historically crucial to liberal student politics, were being actively abandoned. It was these first sparks of agitation that originally ignited the German student movement, represented by the Sozialistischer Deutscher Studentenbund (SDS) and a number of other attendant extra-parliamentary agencies.

Unlike many protest movements of the past, the body of the SDS was not foreign to the rulers they criticized. As a result, "the dominant parent culture...sensed that this protest movement [was] emerging from its own center the middle class." They emerged as an educated and engaged contingent, which felt society was partaking in mass historical repression. The students' initial discontent, contained and pressurized in the universities, was fanned further by the winds of the I96os. By I966, the new SPD had formed a grand coalition government with the more conservative Christlich Demokratische Union Deutschlands (CDU), making it "nearly impossible to articulate opposition views outside of the two dominant political parties." ${ }^{6}$ The new coalition enacted policies 
showing no regard for recent history, proposed by leaders implicated in the recent atrocities of National Socialism. Kurt Georg Kiesinger was accepted as Chancellor, despite his involvement in the Third Reich, and Franz Joseph Strauß was appointed finance minister, despite his numerous attempts to limit the free voice of the German press. ${ }^{7}$ The appointment of these men, readily indictable of antidemocratic activity, appeared as a flagrant dismissal of history in the eyes of the students, and the policies they sought to pass appeared reminiscent of times both recent and repressive. With precisely these concerns in mind, the students criticized the proposed emergency laws of the grand coalition, which would endow the government with overarching power in times of vaguely defined "crisis," due to their similarity to the Weimar laws of the I930s. ${ }^{8}$ Politics at large seemed at best conservative, at worst regressively forgetful. As Belinda Davis of Rutgers University notes, a variety of obstacles caused the students to create their own sphere of thought. This independent space allowed "alternative modes of living...offering protection from repression," a place where they could critically address the present and, ultimately, the past. 9

Here, then, is the scent of the real issue, by which the student movements can be understood as engaging in a discourse not only on the present, but also on the not-distant past - a generation's reaction to the reviving of a smell repressed, and their insistence that it not be perfumed. Their critique, and the sphere they created to propagate it, began to expand intellectually beyond the present situation in the universities to the images and memories of fascism lingering in society at large, which, in Sabine Von Dirke's words, "overshadowed the democratic-humanitarian rhetoric of mainstream West Germany with which the youth had grown up." Iо In this sense, the students' insistence on recalling the "functions of fascism" in the I920s and I930s can be understood. Dutschke's indictment that "After the second world war a new form of fascism" arose can also be interpreted through this perspective. ${ }^{\text {II }}$ Fearing a revival of authoritarian principals, the students, barred from parliament and the orthodox university, founded a critical perspective backed by their own interpretation of recent history. The core methodological backings of the move- ment were, in their very nature, a recollection of recent intellectual history. Much of the movement's method was based upon the revival of the Frankfurt School, that famous house of Critical Theory, which had been "partially lost due to Nazism and partially repressed." ${ }^{12}$ Theodor Adorno, a member of the Frankfurt School contemporary to the student movement, surmised the student's opposition to authoritarianism when he wrote of "the bestial fury of the Brownshirts" against those critical of them as the "incursion of the wild horde into the preserve of the mind." ${ }^{13}$ The reader does not miss the historicity of the phrase, in its explicitly critical memory of National Socialism. But Adorno went further, diagnosing modernity, explicating a mood, and endowing the students with a guiding method, when he stated that the critic would "have willingly excelled the less clever tyrants who were to succeed him", arguing that the once usurped critic now reigns rather than thinks; it was the students' contention and expansion that this is a particularly apt analysis in the realm of politics. ${ }^{14}$ The goal, then, was to actively keep the past of fascism in mind as a means of critiquing the present. The movement's very method was a historical revival, opposed both to fascism and forgetting. The students' main mode was memory. Theirs was the realization that the modern Germany hegemony, to quote Schmidtke, "paralleled the traumatic Weimar experience," and thus threatened to bring about equally traumatic consequences. ${ }^{15}$

Tracing the premise that the students borrowed their memory and their historical method from the Frankfurt School, the manner in which they advanced Adorno's realization that "once culture itself has been debased to 'cultural goods'...it has already defamed its raison d'être” must be observed. ${ }^{16}$ Rather than theorizing about cultural debasement, the students attempted to actively engage the forces responsible for its defamation. Herbert Marcuse, in writing on the student movements, noted that the first movement of the students was one of negation, a refusal "to participate, to play along, [out of] disgust with the lifestyle of the 'affluent society.'" '17 This negation then desired motion, incapable of being contained within the university. In I966, following a series of sit-ins at the Free University of Berlin, the students passed a resolution in which

\section{"The appointment of these men, readily indictable of antidemocratic activity, appeared as a flagrant dismissal of history in the eyes of the students."}




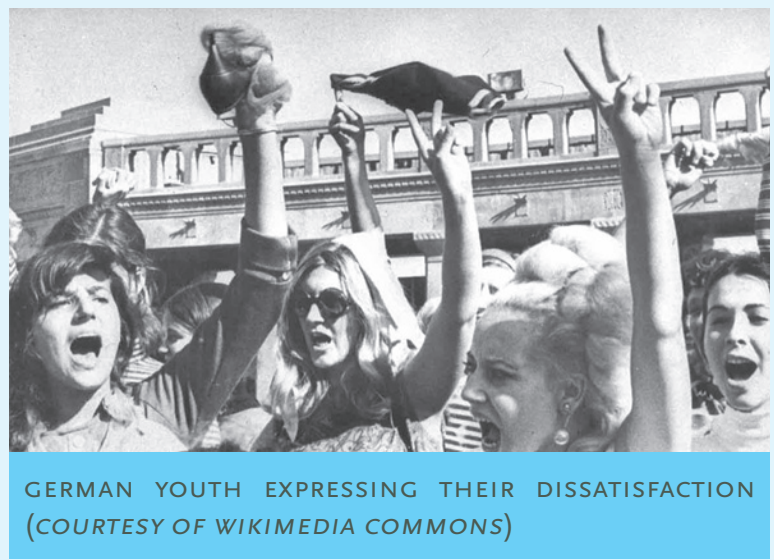

they stated that their movement was "about viewing freedom in the university as a problem that points beyond the realm of the university itself." 18 This required a move into society at large, propagated by subversive political action, inspired by the Frankfurt School, and based on the belief that such actions "could result in 'moments of self-consciousness' for the protester" which would then spread across culture. ${ }^{19}$ Convinced that the situation in the university was, as Rudi Dutschke phrased it, "closely interlocked with the entire structure of society and government in a late-capitalist society," the students sought to engage with power structures which ensured the status quo by denying the continued presence of fascistic tendencies - those hidden tendencies which sought to reify and sterilize culture and history. ${ }^{20}$ These protestors, with their critical methodology in hand, "developed a strategy which aimed to create situations where power structures would be unveiled, and where participants would define themselves independently from authority." ${ }^{21}$ This critical revelation of power is seen in the protests against the Shah's visit to Germany in June of I967. As a student-produced pamphlet described, the protestors were objecting to a leader who had "been shown to have tortured and murdered hundreds of politicians, journalists, students, and workers" a despot who embodied every authoritarian tendencies. ${ }^{22}$ However, despite various accounts of police brutality and the murder of student activist Benno Ohnesorg, the protestors remained peaceful, establishing themselves as the antithetical, historically aware opposition. They used this antithesis, the stark contrast of violence and peace, to generate rhetorical power. The only crime that the students were guilty of, as their pamphlet said, was "speaking out for freedom, democracy, and social justice." ${ }^{23}$ The students were unquestionably successful in bringing power structures to light — forcing both contemporary German soci- ety and twenty-first entury historians to reckon with the fact that the SPD, in the words of Davis, "oversaw the suppression of nonviolent oppositional...expression arguably more repressively than had [the CDU]." ${ }^{24}$ The question arose as to whether the SPD was not more "right," even more authoritarian, than it had originally appeared. More generally, the potential for formerly politically progressive parties to be ideologically debased as the result of political success was poignantly brought to light. The movement's antiauthoritarianism, its main mode of leaving the strictures of the university, was also historical in nature, calling into question not only their current leaders, but also the regimes of Adenauer and the Third Reich and what they saw as their repressive tendencies - seeking to engage more with the public and bring it to awareness. ${ }^{25}$

Rather than a movement of divisive violence, Rudi Dutschke, the SDS, and the students in general sought a universal "coalition of workers and students in the organizational form of [revolutionary] councils." ${ }^{26}$ Despite the violence generated by the authoritarian camp, the students strove to remain peaceful. In an interview with Der Spiegel regarding his critique of the Springer Press, Dutschke explicitly stated, "Violence, murder, and killing...would be wrong and virtually counterrevolutionary" — in this sense, they would also be ahistorical, reminiscent of the fascism the students sought to critique. ${ }^{27}$ The object was to move into society at large, to expand their view's power while establishing a broader base of support. Through this broad union, the movement would establish "scholarship that bases its analysis on present-day conflict situations throughout the world." ${ }^{28}$

It is now possible, with Dutschke's idea of a self-aware, active scholarship, to see the manner in which a generational movement -- critically aware, highly educated, antagonistically seeking unity -- presented a unique means of coming to terms with Germany's unique past. It is in this sense that Dutschke's "Students and the Revolution," dealt with earlier, can be understood. Dutschke argued that "German fascism has lost its definite historical form" - in other words, though the iconic party of fascism was recently dethroned, elements of its ideology persisted, colonizing various elements of political, social, and intellectual life. ${ }^{29}$ The students' goal was to bring this to the attention of the world at large. All the movement's actions should be seen in precisely this light, as a vigorous viewing and criticism of all forms of fascism, both historical and present. Emerging from this movement was a new, antagonistic history, one that opposes the idea that "history is a result of the 
personalities of world history," the notion that "bourgeoisie thinking can only understand the conflict in society...as a result of outstanding individuals." ${ }^{\circ}$ In Dutschke's argument, the students and their work produce a method "that emancipates and that does not need leaders as chief ideol- guage whose rigid, formulaic shorthand" forms a "new esoteric party lingo" - the students began to appear as yet another political body. ${ }^{36}$ Yet more problematic, the once peaceful protest moved to one of active, militaristic violence. The Red Army Faction, a splinter group formerly

\section{"The goal, then, was to actively keep the past of fascism in mind as a means of critiquing the present."}

ogist," constituted by a mass of individuals characterized by "the fact that they take part in a steady critical dialogue," aware that "any personal powers they have can be removed at any time." ${ }^{11}$ This call to work was a call to responsibility, to awareness, and to resolution. Aware of history and the dangers of authority, the movement finally returned, though altered, to one of its foundational thinkers, Adorno, in his invective that criticism must "become aware of its own questionable position." ${ }^{32}$

To end on such a laudatory note, though, would be to miss the critical point. The turbulence that followed the end of the movement questioned the very basis on which it seemed founded. Following an attempt on Dutschke's life, a wave of violent protests, breaking from the previously peaceful tones of the movement, arose - culminating on Easter Sunday, when a massive brawl broke out between students and police. As Schmidtke notes, these riots "marked a turning point for the student movement in Germany" - the observable fracture that portended a shattering. ${ }^{33}$ In the following months, the movement continued to split, and by the SDS conference of I968, the various conflicting ideals of the movement "became obvious... paralyz[ing] further activities." ${ }^{34}$ In the instant of its final iteration, as "the focus shifted away from...individual subjectivity to that of social class," the movement lost the collectively individualistic force, the constant critique with history in mind, which inspired it in the first place. ${ }^{35}$ Without the strong, individual voice of Dutschke, the movement lost much of its collective will. In a philosophical sense, this acts to bring to light the rather odd aporia of a movement seeming to seek collective consciousness predicated upon individual acts of critique. Pragmatically, the movement failed to achieve of any of its aims in full: the emergency laws ultimately passed, the universities saw no sweeping reform, and there was no grand calling to consciousness. Horst Krüger, a critic of the students, may have been right in stating that the students "spoke a lan- affiliated with the SDS, viewed violence "as a simultaneous act of emancipation and defense" that would "force the state to reveal openly its fascism," and terrorized Germany in the I970s. This was clearly hypocritical in view of the movement's original, peaceful, antifascist intent, yet it is also a violently clever reappropriation, revealing the frightening mutability of the student's rhetoric. ${ }^{37}$

That a movement aiming to function outside of governmental strictures ultimately adopted the language of a political party, and that a peaceful antifascist movement resolved in violence's authority obviously questions its historical awareness. Perhaps, though, rather than making present analysis impossible, this reality can be used to better circumscribe a historically significant moment. While the movement, like so many others, petered out, it was for a time aware, as analysis has shown. As Von Dirke notes, "The Frankfurt Auschwitz Trial in I965 ... introduced the majority of the German youth for the first time to the horrors of the Holocaust and heightened their sensibility for the question of historical failure and guilt." ${ }^{38}$ With a new generation came a hope for new thought and fresh eyes. Adorno, though not a member of the student's generation, stated that "to write poetry after Auschwitz is barbaric." 39 It is precisely this realization, of the utter barbarism and deep-seated unacknowledged hypocrisy that lay at the heart of contemporary Germany, which the students at their highest moment achieved. For this reason, the refusal of German society to allow the students, in their call to consciousness, to develop into a call to dogmatism and violence, perhaps showed the first signs of coming to terms with those atrocities which had just so recently, and so querulously, ended. 


\section{ENDNOTES}

I. Rudi Dutschke, "The Students and the Revolution (7 March I968)" in The Global Revolution of 1968 ed. Jeremi Suri trans. Patricia Howard (New York: Norton, 2007) I22.

2. Michael A. Schmidtke, "Cultural Revolution or Cultural Shock? Student Radicalism and I968 in Germany," South Central Review I6/I7 (December I, I999) 78.

3. Willibald Karl, "Students and the Youth Movement in Germany: Attempt at a Structural Comparison," Journal of Contemporary History 5, no. I (January I, I970): II4.

4. Schmidtke, "Cultural Revolution or Cultural Shock?," 78.

5. Sabine Von Dirke, "All Power to the Imagination!" : the West German Counterculture from the Student Movement to the Greens (Lincoln: University of Nebraska Press, I997), 31.

6. Schmidtke, "Cultural Revolution or Cultural Shock?," 8 o.

7. Schmidtke, $78-79$.

8. Schmidtke., 79

9. Belinda Davis, "What's Left? Popular Political Participation in Postwar Europe," The American Historical Review II3, no. 2 (April I, 2008): 370 .

Io. Von Dirke, All Power to the Imagination!, 3I.

II. Dutschke, "The Students and the Revolution (7 March I968)" I2I.

I2. Von Dirke, All Power to the Imagination!, 32.

I3. Theodor Adorno, "Cultural Criticism and Society" in Prisms ed. Theodor Adorno trans. Samuel and Shiery Webber (Cambridge: The MIT Press, I98I) 22.

I4. Ibid.

I5. Schmidtke, "Cultural Revolution or Cultural Shock?," 8I.

I6. Adorno, "Cultural Criticism and Society," 22.

I7. Marcuse, Herbert, "Herbert Marcuse Denounces the Vietnam

War (May 22, I966)" trans. Allison Brown. German History in Documents and Images. I9 April 20I4, http://ghdi.ghidc.org/sub_ document.cfm?document_id $=890$

I8. Bergmann, Uwe, "The "Sit-In" as a Means for Reforming the University (June 22, I966)" trans. Allison Brown German History in Documents and Images. I9 April 20I4, http://ghdi.ghi-dc.org/ sub_document.cfm?document_id=89I

I9. Schmidtke, "Cultural Revolution or Cultural Shock?," 83. 20. Dutschke, Rudi, "The Students and the Revolution," II5. 2I. Schmidtke, "Cultural Revolution or Cultural Shock?," 83. 22. Social Democratic Student Association "Social Democratic Student Association Flyer on the Death of Benno Ohnesorg (June 3, I967)" trans. Allison Brown. German History in Documents and Images. I9 April 20I4, http://ghdi.ghi-dc.org/docpage. cfm?docpage_id=I620

23. Ibid.

24. Davis, "What's Left?". II7.

25. Sabine Von Dirke, All Power to the Imagination!, 33.

26. Ibid.

27. Dutschke, Rudi, "Rudi Dutschke Demands the Expropriation of the Springer Press Empire (July IO, I967)" trans. Allison Brown. German History in Documents and Images. I9 April 2014, http://ghdi.ghi-dc.org/sub_document.cfm?document_id=893 28. Ibid
29. Dutschke, Rudi, “The Students and the Revolution," II8. 30. Ibid., I28

3I. Ibid., I29.

32. Adorno, Thodor, "Cultural Criticism and Society," 28.

33. Schmidtke, "Cultural Revolution or Cultural Shock?," 87.

34. Webler, "The Sixties and the Seventies," I57.

35. Von Dirke, All Power to the Imagination!, 33.

36. Horst Krüger, "Liberal Musings on the Character of the Generational Revolt (October I8, I968)” trans. Allison Brown. German History in Documents and Images. I9 April 20I4, http://ghdi.ghidc.org/docpage.cfm?docpage_id= 126

37. Karrin Hanshew, "Daring More Democracy? Internal Security and the Social Democratic Fight Against West German Terrorism," Central European History 43, no. I (March I, 2010): II7. 38. Sabine Von Dirke, All Power to the Imagination!, I38.

39. Adorno, Theodor, "Cultural Criticism and Society," 34.

\section{REFERENCES}

Adorno, Theodor, "Cultural Criticism and Society" in Prisms edited by Theodor Adorno, translated by Samuel and Shiery Webber (Cambridge: The MIT Press, I98I): I734 .

Bergmann, Uwe, “The "Sit-In" as a Means for Reforming the University (June 22, I966)" translated by Allison Brown German History in Documents and Images. Accessed April I9, 20I4, http://ghdi.ghidc.org/sub_document. cfm?document_id=89I

Davis, Belinda. "What's Left? Popular Political Participation in Postwar Europe." The American Historical Review II3, no. 2 (April I, 2008): 363-90.

Dutschke, Rudi, "Rudi Dutschke Demands the Expropriation of the Springer Press Empire (July Io, I967)" Translated by Allison Brown German History in Documents and Images. Accessed April I9, 20I4, http://ghdi.ghidc.org/ sub_document.cfm?document_id=893

Dutschke, Rudi, "The Students and the Revolution (7 March I968)" in The Global Revolution of 1968 edited by Jeremi Suri translated by Patricia Howard (New York: Norton, 2007): II8-I3I.

Hanshew, Karrin. “Daring More Democracy? Internal Security and the Social Democratic Fight Against West German Terrorism." Central European History 43, no. I (March I, 20IO): II7-47. 
Karl, Willibald. "Students and the Youth Movement in Germany: Attempt at a Structural Comparison." Journal of Contemporary History 5, no. I (January I, I970): II3-27.

Krüger, Horst, "Liberal Musings on the Character of the Generational Revolt (October I8, I968)" Translated by Allison Brown German History in Documents and Images. Accessed April I9, 20I4, http://ghdi.ghidc.org/docpage. cfm?docpage_id=I26

Marcuse, Herbert, "Herbert Marcuse Denounces the Vietnam War (May 22, I966)" translated by Allison Brown German History in Documents and Images. I9 April 2014, http://ghdi.ghidc.org/sub_document.cfm?document_ id $=890$

Sabine Von Dirke. "All Power to the Imagination!" : the West German Counterculture from the Student Movement to the Greens. Lincoln: University of Nebraska Press, 1997.

Schmidtke, Michael A. "Cultural Revolution or Cultural Shock? Student Radicalism and I968 in Germany." South Central Review I6/I7 (December I, I999): 77-89.

Socialist Democratic Student Association, "Socialist Democratic Student Association Flyer on the Death of Benno Ohnesorg (June 3, I967)" translated by Allison Brown German History in Documents and Images. Accessed April I9, 20I4, http://ghdi.ghidc.org/docpage.cfm?docpage_ $\mathrm{id}=\mathrm{I} 620$

Webler, Wolff-Dietrich. "The Sixties and the Seventies: Aspects of Student Activism in West Germany." Higher Education 9, no. 2 (March I, I980): 155-68. 